\title{
DOI https://doi.org/10.30525/978-9934-26-112-1-7
}

\section{ВАРІАТИВНИЙ МОДУЛЬ «СТЕП-АЕРОБІКА» В СТРУКТУРІ НАВЧАННЯ ФІЗИЧНОЇ КУЛЬТУРИ УЧНІВ ЗАГАЛЬНООСВІТНІХ НАВЧАЛЬНИХ ЗАКЛАДІВ}

\author{
Григоренко Г. В. \\ кандидат педагогічних наук, \\ доцент кафедри методик викладання \\ спортивно-педагогічних дисииплін \\ ДВНЗ «Донбаський державний педагогічний університет» \\ Григоренко Д. П. \\ асистент кафедри методик викладання \\ спортивно-педагогічних дисииплін \\ ДВНЗ «Донбаський державний педагогічний університет» \\ м. Слов'янськ, Украӥна
}

Реформування сучасної системи освіти визначає напрямки змістових ліній, які визначають формування та вдосконалення життєвих компетентностей учнів загальноосвітніх навчальних закладів. У навчальній програмі з фізичної культури для 5-9 класів зазначається, що при вивченні змістової лінії «Здоров’я і безпека» педагогічні працівники «прагнуть сформувати учня/ученицю як духовно, емоційно, соціально і фізично повноцінного члена суспільства, який/яка здатний на дотримуватися здорового способу життя i формувати безпечне життєве середовище. Розуміти, що фізична культура є складовою частиною загальної культури суспільства, спрямована на зміцнення здоров'я, розвиток фізичних, морально-вольових та інтелектуальних якостей людини 3 метою гармонійного формування іiї як особистості» [3]. Фізичне виховання в освітній сфері має закласти основи забезпечення та розвитку фізичного здоров'я учнів, особистісно орієнтованого формування їх культури здоров'я, розумової, рухової, психосоматичної та суспільної діяльності, підготовки до активного життя. Означений підхід здійснюється в умовах безперервності на засадах принципів індивідуалізації, пріоритету оздоровчої спрямованості, використання можливостей освітньо-оздоровчого середовища загальноосвітніх навчальних закладів, різноманітних методичних підходів, сучасних технологій фізичного виховання й оздоровлення учнів $[2,3,5]$. 
Навчальна програма 3 фізичної культури для загальноосвітніх навчальних закладів (5-9 класи), що побудована за модульною системою, містить інваріантну та варіативну складову. Якщо інваріантна частина передбачає обов'язкове набуття теоретичних знань та загальної фізичної підготовки, то у варіативному модулі може вивчатися окремий вид спорту, при обранні якого враховуються матеріально-технічні можливості навчального закладу, фахову й методичну підготовку вчителя з обраного виду спорту, оптимальні умови для проведення уроків фізичної культури тощо.

У нашому дослідженні ми надаємо теоретичний аналіз та загальну характеристику ефективності застосування варіативного модулю «Степ-аеробіка» в структурі навчання фізичної культури учнів загальноосвітніх навчальних закладів. Автори-розробники програми I. В. Бакіко та А. В. Цьось наводять загальний зміст навчального матеріалу, характеризують очікувані результати діяльності учнів. Вони зазначають, що «степ-аеробіка укріплює всі основні групи м'язів, опорно-руховий апарат, розвиває рухливість суглобів, формує зведення стоп, тренує рівновагу, дозволяє спалювати стільки калорій, скільки витрачається за той же час при швидкому бігу, зміцнює серцевосудинну систему» [3]. Модуль передбачає набуття учнями теоретичних знань, спеціальної та техніко-тактичної підготовки протягом 5 років навчання.

Питанням ефективності добору фізичних вправ 3 фітнесу для формування рухової активності та психофізичного розвитку учнів присвячені дослідження Т. Круцевич, Г. Лисицької, Т. Ротерс, А. Цьось, Б. Шияна та інших. Методики організації учнів та практичне впровадження степ-аеробіки на уроках фізичної культури висвітлені у багатьох роботах О. Бабешко, Г. Глоби, В. Завадич, Т. Киреєвої, Д. Солопчук, І. Степанової.

Для уточнення мотивації до занять фізичною культурою ми провели вибіркове опитування учнів 6-9 класів. Майже всі респонденти зацікавлені у тому, щоб вчителі включали сучасні напрями фітнесу у шкільний навчально-виховний процес. Дані опитування вказують на те, що зацікавленість учнів заняттями фізкультури обумовлена: - можливістю сприяти розвитку фізичних якостей та зміцненню свого здоров'я 3 допомогою вчителя; - отриманням необхідної інформації щодо сучасних фітнес-технологій та їх використання в умовах школи та у побуті; бажанням виглядати привабливим, формувати своє тіло, активний стиль життя під керівництвом спеціалістів; - привабливими та різноманітними формами й методами проведення уроків фізичної культури та шкільних заходів; - вихованням самодисципліни та 34 
самовдосконалення; - можливістю подолання особистих комплексів та самоствердження. Учні також зазначили, що позитивно сприймають елементи сучасних фітнес-технологій на уроках фізкультури і в позакласних заходах, тому що вони стали більш цікавими.

Ми також провели опитування серед вчителів фізичної культури $(\mathrm{n}=14)$, у якому ключовим питанням було «Чи готові Ви до впровадження в освітній процес варіативних модулів, що рекомендовані навчальною програмою з предмету?» Ми можемо зазначити: - 85,7\% вчителів готові до впровадження декількох модулів у освітній процес після набуття/вдосконалення навичок з обраного виду спорту; - 71,4\% визнали, що для досягнення позитивного оздоровчого ефекту вчителям фізкультури не завжди вистачає знань 3 теорії й методики впровадження і використання сучасних фітнес-технологій; $-35,7 \%$ вчителів повністю готові впроваджувати (фрагментарно - на уроках фізичної культури або системно у структурі навчального року). Окремо виділяємо й той факт, що всі вчителі вважають доцільним проведення тренінгів, семінарів, майстер-класів з впровадження новітніх оздоровчих технологій в освітній процес сучасної школи, які можуть бути організовані при навчально-методичних центрах, під час проходження стажування або підвищення професійно-педагогічної кваліфікації.

Аналізуючи сучасні програми зі степ-аеробіки зазначаємо, що вони містять достатню методичну базу, яка забезпечує високу ефективність заняття $[1,4]$. Фізичні навантаження на заняттях степ-аеробікою регулюються залежно від року навчання, обраної висоти платформи, складності рухів. Багато учнів мають низьку танцювальну підготовку, тому вчителі передбачають можливість засвоєння координації рухів на платформі й навкруги неї без хореографії та складних стрибків. Основна методична умова їх виконання - оптимальна для учнів висота платформи.

Bci вправи у Basic Step виконуються у середньому темпі, що дозволяє учням самостійно корегувати навантаження на м'язи ніг, а енергійні рухи руками допомагають їм контролювати ритм дихання та забезпечують вплив на м'язи верхньої частини тіла. Step I рекомендується для учнів, які вже навчались 2-3 роки та мають базові знання, середній рівень спеціальної та техніко-тактичної підготовленості, який характеризується тим, що вони виконують загальнорозвивальні та танцювальні вправи самостійно або з групою товаришів в заданому ритмі і темпі з певною амплітудою та узгодженістю рухів.

Степ-кроки - основні та поперемінні - виконуються на рахунки (4 та 8 відповідно). Тому доцільним $є$ використання музичного супроводу під час виконання вправ, який вчитель підбирає згідно 
методичних вимог, поставленої мети заняття та враховує побажання учнів. Змінюючи темп музики, вчитель може корегувати інтенсивність навантаження, тривалість інтервалів відпочинку, при цьому необхідний постійний візуальний контроль за загальним станом самопочуття учнів. Автори програми варіативного модулю «Степ-аеробіка» наголошують: «стежте за тим, щоб дихання було ритмічним, неускладненим, без затримок» [3].

Спрямованість основних частин уроку передбачає різний ступень навантаження та інтенсивності виконання вправ. Розминка (предстретчинг) передбачає низьку й середню інтенсивність, основна частина використання платформи зі зростанням максимального навантаження, заключна (стретчинг) - вправи на розслаблення, релаксацію.

Вчитель при складанні навчального плану та конспекту уроків має в їх основу покласти оптимальний характер обсягу навантаження та інтенсивності виконання вправ, що мають максимальний вплив та можливість корекції їх показників для учнів. Ефективність впливу обраного модулю «Степ-аеробіка» на фізичну підготовленість учнів визначається під час оцінювання (проміжного та підсумкового). Кри-терії оцінювання (низький, середній, достатній, високий) автори модулю «Степ-аеробіка» наводять у основних навчальних нормативах, які характеризують якості засвоєного матеріалу (базові теоретичні знання, технічна та спеціальна фізична підготовка) кожного року навчання, а також рівень сформованості компетентності. Рекомендовані орієнтовні навчальні нормативи надають можливість вчителю системно відслідковувати ефективність впливу вправ та урізноманітнювати методику проведення занять в цілому. Учні можуть виконувати фізичні вправи також самостійно, при цьому дотримуючись правил безпеки під час занять. Позитивною оцінкою діяльності вчителя фізичної культури є зростання мотивації учнів до рухової активності, до занять степ-аеробікою не тільки у освітньому закладі, але й під час дозвілля.

\section{Література:}

1. Бабешко О., Завадич В. Уроки степ-аеробіки в школі. Фізичне виховання в школі. 2007. № 2. С. $42-48$.

2. Григоренко В.Г. Педагогічні технології особистісно орієнтованого формування в учнів загальноосвітньої школи культури здоров'я: теорія та практика /за ред. В.Г.Григоренка, С.О. Омельченко. Слов'янськ: Вид-во СДПУ, 2010. 346 с.

3. Навчальна програма 3 фізичної культури для загальноосвітніх навчальних закладів 5-9 класи. URL: https://mon.gov.ua 
4. Солопчук Д. Використання степ-аеробіки на уроках фізичної культури. Фізичне виховання в школі. 2007. № 1. С. 48 - 52.

5. Худолій О. М. Загальні основи теорії і методики фізичного виховання: Навч. посібник. 2-е вид., випр. Харків: «ОВС», 2008. 406 с.

\title{
DOI https://doi.org/10.30525/978-9934-26-112-1-8
}

\section{TEAM BUILDING НА УРОКАХ ФІЗИЧНОЇ КУЛЬТУРИ}

\author{
Грузевич Т. В. \\ вчитель фізичної культури \\ Комунальний заклад «Якушинещький ліией» Вінниџької області \\ с. Якушиниі, Вінницька область, Україна
}

Фізична культура необхідна дітям і підліткам, оскільки в їхньому віці закладається фундамент фізичного розвитку і здоров'я.

Оскільки застарілі методи навчання, нормативи та відсутність інвентарю відштовхують дітей від уроків фізкультури, та й взагалі від спорту, вирішила зацікавити дітей, дати їм можливість обирати для себе той вид спорту, який їм до вподоби.

Нам, вчителям фізкультури, часто доводиться формувати команди 3 учнів різних вікових категорій, різних класів для участі в різноманітних змаганнях, а також проводити уроки в одному спортивному залі 3 учнями різних класів. Саме тому почала впроваджувати елементи тімбілдингу на уроках фізичної культури.[5]

Командоутворення, або тімбілдінг (англ. Team building - побудова команди) - термін, що часто використовується в контексті бізнесу і застосовуваний до широкого діапазону дій для створення та підвищення ефективності роботи команди. [1]

Чому тімбілдінг так необхідний в дитячому колективі? За допомогою тімбілдінга дитина зможе уникнути серйозних труднощів у спілкуванні і дасть надійний фундамент для успішної реалізації себе в майбутньому. дитячий тімбілдінг - це активний відпочинок, захід (гра) сприяє розвитку здатності відчувати себе впевненим нерозривним ланкою однієї команди. За допомогою модулювання ситуації всі члени однієї команди напрацьовують корисні навички для спільного досягнення мети, взаємної допомоги один одному, знаходять задоволення від активного обміну емоціями, перемагаючи приховані 